\title{
Cutaneous Anthrax-Still a Reality in India
}

\author{
Devinder Mohan Thappa ${ }^{1}$
}

Address for correspondence Devinder Mohan Thappa, MD, DHA, FRCP, FAMS, FIMSA, North Eastern Indira Gandhi Regional Institute of Health and Medical Sciences, Mawdiangdiang, Shillong 793018, Meghalaya, India (e-mail: dmthappa@gmail.com).

\begin{abstract}
Keywords

- chemical extract of anthrax

- Bacillus anthracis

- inhalational anthrax

- bioterrorism

- injectional

Anthrax, a toxigenic zoonosis, incidentally affecting humans has become rare but endemic outbreaks still continue to occur in tropical countries like India, parts of South America, and Europe where veterinary control of livestock is marginal and environmental conditions favor an animal-soil-animal cycle. India, with its largest population of livestock in the world, continues to have anthrax outbreaks with highest incidence reported from south, and the authors have reported an outbreak of 23 cases from 1998 to 2001 from south India. Children outnumbered adults and most of them had lesions on the exposed sites. However, there is a limited documentation of anthrax outbreaks from India warranting the need for sensitizing and creating awareness among health care professionals to identify and report these cases at the earliest so that appropriate actions are taken. Anthrax continues to retain a certain fascination and notoriety because of the potential for use of the bacillus spores in biologic warfare.
\end{abstract}

\section{Introduction}

Anthrax occupies an important place in the history of infectious diseases, as it is the first human disease to be attributed to a specific pathogen..$^{1,2}$ It is a zoonotic infection with Bacillus anthracis. The name anthrax comes from a Greek word for "coal," a reference to black eschar that is eventually formed in cutaneous anthrax.

Human anthrax is of four clinical forms depending on the route of transmission: cutaneous (the most common form accounting for nearly $95 \%$ of all anthrax cases), inhalational, ingestion form, and injectional form. ${ }^{3}$

\section{History}

In 1876, Robert Koch (1843-1910) reproducibly transmitted anthrax to mice by inoculating them with blood from the cattle and subsequently, he then recovered the same rod-like bacteria from the sick mice as came from the cattle. He could pass the disease from one mouse to another by inoculating them with these pathogens. Based on his experiments, he proposed the "Henle-Koch postulates" for proof that a microorganism was the cause of an infectious disease. ${ }^{4}$

Robert Koch's landmark work on anthrax helped to establish the germ theory of disease, and an 1877 report on
B. anthracis included the first published photomicrographs of any bacteria. ${ }^{3}$

B. anthracis is a large (1-5 micron), spore forming aerobic, or facultative anaerobic gram-positive rod, usually arranged in a box-car pattern. ${ }^{1,5}$ When cultured on $5 \%$ sheep blood agar, 2 to $5 \mathrm{~mm}$ colonies have ground glass appearance with nonhemolytic, tenacious colonies (beaten egg-white appearance) after 15 to 24 hours. On India-ink staining, poly-D glutamic acid capsule can be visualized. On methylene blue staining, the bacterial cell is stained blue, whereas the surrounding capsule is pink. This is described as the M'Fadyean's reaction. Koch's postulates were proved on this organism for the first time. ${ }^{5}$

\section{Epidemiology}

Being a zoonotic infection anthrax is mainly linked to goat, sheep, cattle, antelope, kudu, pigs, horses, zebu, and other animals. ${ }^{6}$ Animals are infected by ingesting the spores from contaminated soil, feed, or even meat (in case of wild animals). It is transmitted to humans by meat, wool, hides, bones, and hairs and rarely from person to person.

Infection in animals commonly occurs due to ingestion of spores or inoculation into abraded perioral areas while grazing in contaminated area or eating contaminated feed
DOI https://doi.org/ 10.1055/s-0039-1698494 ISSN 0379-038X.
License terms

$($ () (1) $\Theta \circledast$ 
or meat. Subsequent death of the animal causes recontamination of the environment. ${ }^{6,7}$ After such multiple events, the area might become endemic. Other modes of spread in animals are fomites, by insects or legs of vultures. ${ }^{6,7}$

Anthrax should be considered as possible cause of death in herbivorous animals that have died suddenly and unexpectedly, especially if hemorrhage from the nose, mouth, or anus has occurred. ${ }^{3}$ Failure of the blood to clot, the absence of rigor mortis, and the presence of splenomegaly are the most significant necropsy findings in such animals. 6,7

The disease has a global distribution but incidence in livestock and humans varies with local ecology, implementation of control strategies, and sociocultural practices that determine spillover from animals to humans. Although most developed countries report few sporadic cases in livestock and humans, the disease is still enzootic in parts of Africa (e.g., Zimbabwe and Chad), the Middle East, Central Asia, China, Pakistan, Bhutan, Bangladesh, and India. ${ }^{1,2,6-15}$

The geographic distribution of anthrax is associated with certain ecological factors. In some ecosystems, outbreaks occur late in the hot-dry season, whereas in others, outbreaks are associated with the end of heavy rains, suggesting that weather extremes may be an important trigger of outbreaks. ${ }^{6}$

One of the largest outbreaks of anthrax occurred in Zimbabwe during 1979 to 1985 where approximately 10,000 cases of cutaneous anthrax were reported. Inhalational anthrax historically referred as "wool-sorters" disease because it occurred in industrial settings where spore contaminated wool or animal hides are handled. 5,16

Anthrax is also mentioned prominently as potential agent of biowarfare and bioterrorism. In the 1950s and 1960s, both the United States and former Soviet Union developed anthrax as a biological weapon, as have other countries. ${ }^{5}$

An epidemic of inhalation anthrax occurred among persons living in Sverdlovsk, Union of Soviet Socialist Republics, in April and May 1979 resulting in at least 96 cases and 66 deaths. ${ }^{17-19}$ This outbreak also affected cattle within the city. It was concluded that this largest outbreak of human inhalation anthrax was due to an infectious aerosol emanating from the military facility. This outbreak raised considerable concern among scientists and policymakers about the potential for the use of aerosolized $B$. anthracis spores as an agent of biological terrorism. Indeed, these fears were confirmed in 2001 when an outbreak of 22 cases of anthrax (11 inhalational and 11 cutaneous) occurred in the United States from intentional contamination of the U.S. mail delivered to several persons by the U.S. Postal Service. Five deaths and 22 cases of anthrax occurred. ${ }^{17-19}$

Since 2009, anthrax has emerged among heroin users in Europe, presenting a novel clinical manifestation, "injectional anthrax," which has been attributed to contaminated heroin distributed throughout Europe; before 2009, only one case was reported. ${ }^{20,21}$ During 2012 and 2013, new cases of injectional anthrax were diagnosed in Denmark, France, Germany, and the United Kingdom. Overall 70 confirmed cases were reported, with 26 fatalities ( $37 \%$ case fatality rate). The latest two confirmed cases occurred in March 2013.20,21

\section{Anthrax in India}

A few sporadic cases and endemic outbreaks have been reported from India. ${ }^{1,2}$ During the last two decades, 70 cases of human anthrax were encountered at the Christian Medical College at Vellore in Tamil Nadu of which 26 cases had cutaneous anthrax. A review of Indian literature in 1996 found 112 cases of anthrax ( 71 cutaneous anthrax cases) in places, other than Vellore. The authors have recorded 23 cases of cutaneous anthrax over a period of 3 years with a single mortality due to septicaemia. ${ }^{1,2}$ Recently, outbreaks of cutaneous anthrax have been recorded from Andhra Pradesh (in the year 2005, 2009, and 2012), and West Bengal (2009).22-25 These data confirm the endemicity of anthrax, besides in the state of West Bengal, in other three southern states of India, that is, Andhra Pradesh, Karnataka, and Tamil Nadu.

\section{Life Cycle of Bacillus anthracis}

- Table 1 depicts the life cycle of B.anthracis., ${ }^{1,20,21}$

\section{Pathogenesis}

Cutaneous inoculation occurs at the site of minor trauma, insect bite or preexisting skin lesions whereas inhalational (pulmonary or Woolsorter's disease) and intestinal forms result from inhalation or ingestion of spores. ${ }^{1,3,5}$

Major virulence factors in B. anthracis known for inflammatory response with hemorrhage and necrosis and gelatinous edema in the tissue are as follows:

1. Edema factor (EF).

2. Lethal factor (LF).

3. Antiphagocytic poly-D glutamic acid capsule.

EF and LF bind with protective antigen (PA) to form EF-PA binary toxin and LF-PA binary toxin. EF causes water and calcium dysregulation resulting into characteristic edema

Table 1 Cycle of Bacillus anthracis

\begin{tabular}{|l|l|l|}
\hline Soil cycle & $\begin{array}{l}\text { Anhrax spores in soil/ } \\
\text { vegetation }\end{array}$ & $\begin{array}{l}\text { Multiplications } \\
\text { (soil contamination) } \\
\text { spread to the herbiv- } \\
\text { orous animals }\end{array}$ \\
\hline $\begin{array}{l}\text { Animal } \\
\text { cycle } \\
\text { (primarily } \\
\text { herbivo- } \\
\text { rous) }\end{array}$ & Animal anthrax & $\begin{array}{l}\text { The infected animals } \\
\text { die and contaminate } \\
\text { the soil and other } \\
\text { water resources }\end{array}$ \\
\hline $\begin{array}{l}\text { Human } \\
\text { cycle }\end{array}$ & $\begin{array}{l}\text { Direct contact with } \\
\text { the animals }\end{array}$ & $\begin{array}{l}\text { Clinical anthrax } \\
\text { (cutaneous, pharyn- } \\
\text { geal, and intestinal) }\end{array}$ \\
\cline { 2 - 3 } & $\begin{array}{l}\text { Indirect contact with } \\
\text { the contaminated } \\
\text { animal products, such } \\
\text { as hair, hides, bones } \\
\text { (Industrial contact) }\end{array}$ & $\begin{array}{l}\text { Clinical anthrax } \\
\text { (cutaneous, } \\
\text { inhalation) }\end{array}$ \\
\hline $\begin{array}{l}\text { Insect } \\
\text { cycle }\end{array}$ & $\begin{array}{l}\text { Insects play role in the transmission } \\
\text { of B. anthracis to humans (cutaneous anthrax) } \\
\text { and domestic animals }\end{array}$ \\
\hline $\begin{array}{l}\text { Injection } \\
\text { cycle }\end{array}$ & $\begin{array}{l}\text { Contaminated heroin injections in Europe } \\
\text { (due to use of animal skin for smuggling) }\end{array}$ \\
\hline
\end{tabular}


of anthrax. It also impairs function of polymorphonuclear leucocytes. LF interferes with normal T-cell function causing excessive production of cytokines and dysregulation of cytokine network leading to cytokine storm resulting in multiorgan failure, shock, and death. It is also responsible for bleeding diathesis. ${ }^{1,3,5}$

\section{Clinical Features}

The lesion of cutaneous anthrax follows the introduction of endospores into the skin. Common sites involved are exposed parts of the body. ${ }^{1,3,5,8,10}$ All ages and both genders may be affected. In rural settings, children minding cattle may be affected. ${ }^{26-33}$ Generally, cutaneous anthrax presents with single lesion but they may be multiple. Fatalities in cutaneous anthrax are mainly due to obstruction of the airways by the edema that accompanies lesions that form on the face or neck but can also occur when cutaneous disease progresses to systemic infection. ${ }^{3}$

Clinical features of various types of anthrax are tabulated in the - Table 2. ${ }^{1,3,5,20,21}$

Table 2 Clinical types, diagnostic features, and prognosis of anthrax

\begin{tabular}{|c|c|c|c|c|c|}
\hline Type & Source of infection & $\begin{array}{l}\text { Incubation } \\
\text { period }\end{array}$ & Clinical features & Laboratory diagnosis & Prognosis \\
\hline $\begin{array}{l}\text { Cutaneous } \\
\text { anthrax }\end{array}$ & $\begin{array}{l}\text { 1. Inoculation into } \\
\text { abraded skin } \\
\text { during skinning } \\
\text { and butchering } \\
\text { of infected } \\
\text { animals } \\
\text { 2. Insect bites }\end{array}$ & $1-12$ days & $\begin{array}{l}\text { The initial skin lesion is papule } \\
\text { develops into vesicle which } \\
\text { rupture to produce necrotic ulcer } \\
\text { surrounded by smaller peripheral } \\
\text { vesicles } \\
\text { Later central black eschar form } \\
\text { and heal with scarring in } 1-2 \\
\text { weeks } \\
\text { Distinctive features are as } \\
\text { follows: } \\
\text { 1. Lesion is painless } \\
\text { 2. Edema out of proportion } \\
\text { 3. Lack of neutrophilic response } \\
\text { 4. Regional lymphadenopathy }\end{array}$ & $\begin{array}{l}\text { Smear from edge of } \\
\text { eschar or vesicular fluid } \\
\text { for } \\
\text { - Gram stain } \\
\text { - PCR } \\
\text { Skin biopsy (full } \\
\text { thickness punch biopsy } \\
\text { from papule, vesicle, or } \\
\text { eschar). } \\
\text { Blood culture } \\
\text { Serodiagnosis (when } \\
\text { culture fails owing to } \\
\text { the previous treatment) } \\
\text { Guinea pig or mouse } \\
\text { inoculation }\end{array}$ & $\begin{array}{l}\text { Sepsis is rare } \\
\text { and mor- } \\
\text { tality is less } \\
\text { than } 1 \% \text { with } \\
\text { adequate } \\
\text { antibiotic } \\
\text { therapy }\end{array}$ \\
\hline $\begin{array}{l}\text { Inhalation- } \\
\text { al anthrax }\end{array}$ & $\begin{array}{l}\text { 1. Contaminated } \\
\text { wools and hides } \\
\text { 2. Bioterrorism }\end{array}$ & 2-43 days & $\begin{array}{l}\text { Flu like symptoms and nonpro- } \\
\text { ductive cough followed by respi- } \\
\text { ratory distress and respiratory } \\
\text { failure }\end{array}$ & $\begin{array}{l}\text { Chest radiograph/ } \\
\text { CT scan: mediastinal } \\
\text { widening due to hem- } \\
\text { orrhagic lymphade- } \\
\text { nopathy, hemorrhagic } \\
\text { pleural effusion, infil- } \\
\text { trate or consolidation } \\
\text { Blood culture } \\
\text { Serodiagnosis }\end{array}$ & \\
\hline $\begin{array}{l}\text { Gastro-in- } \\
\text { testinal } \\
\text { anthrax }\end{array}$ & $\begin{array}{l}\text { 1. Consump- } \\
\text { tion of raw or } \\
\text { under-cooked } \\
\text { meat }\end{array}$ & 2-144 hours & $\begin{array}{l}\text { Oropharyngeal: severe sore- } \\
\text { throat, swelling of neck, regional } \\
\text { lymphadenopathy, dyspnea and } \\
\text { fever } \\
\text { Intestinal: present with hem- } \\
\text { orrhagic gastro-enteritis which } \\
\text { may lead to obstruction, or per- } \\
\text { foration. It is due to hemorrhagic } \\
\text { ulceration which appear in muco- } \\
\text { sa of terminal ileum or cecum }\end{array}$ & $\begin{array}{l}\text { Gram staining in infect- } \\
\text { ed fluids or blood } \\
\text { Blood culture } \\
\text { Serodiagnosis } \\
\text { Guinea pigs or mouse } \\
\text { inoculation }\end{array}$ & $\begin{array}{l}\text { Case fatality } \\
\text { is very high }\end{array}$ \\
\hline $\begin{array}{l}\text { Injection } \\
\text { anthrax }\end{array}$ & $\begin{array}{l}\text { Contaminated her- } \\
\text { oin injections due } \\
\text { to use of animal } \\
\text { skin for smuggling }\end{array}$ & & $\begin{array}{l}\text { Serious soft tissue infection with } \\
\text { significant edema }\end{array}$ & $\begin{array}{l}\text { Tissue biopsy } \\
\text { Blood culture } \\
\text { Serodiagnosis }\end{array}$ & $\begin{array}{l}\text { Progression } \\
\text { to septic } \\
\text { shock can be } \\
\text { rapid }\end{array}$ \\
\hline $\begin{array}{l}\text { Anthrax } \\
\text { menin- } \\
\text { go-en- } \\
\text { cephalitis }\end{array}$ & $\begin{array}{l}\text { Usually associ- } \\
\text { ated with inha- } \\
\text { lational and Gl } \\
\text { anthrax, rarely with } \\
\text { cutaneous }\end{array}$ & & $\begin{array}{l}\text { - Cerebral edema } \\
\text { - Parenchymal brain } \\
\text { hemorrhage } \\
\text { - Vasculitis } \\
\text { - Subarachnoid hemorrhage }\end{array}$ & $\begin{array}{l}\text { CSF and blood culture } \\
\text { Gram staining }\end{array}$ & $\begin{array}{l}\text { Nearly always } \\
\text { fatal }\end{array}$ \\
\hline
\end{tabular}

Abbreviations: CSF, cerebrospinal fluid; CT, computed tomography; GI, gastrointestinal; PCR, polymerase chain reaction. 


\section{Differential Diagnosis}

Cutaneous anthrax needs to be differentiated from vaccinia, Milker's nodule, orf (ecthyma contagiosum), and furuncle. Painless eschar, with profound edema and lack of neutrophilic response gives clue to the diagnosis of cutaneous anthrax supplemented by Gram's stained smear and culture of the B.anthracis. ${ }^{1,3,5}$ The anthraxin skin test, consisting of subdermal injection of a commercially produced chemical extract of an attenuated strain of B.anthracis, is now available for the diagnosis of acute and previous cases of anthrax. ${ }^{1}$

\section{Treatment}

The most commonly used antibiotics are mentioned below:

- Ciprofloxacin.

- Erythromycin.

- Tetracycline/doxycycline.

- Chloramphenicol.

In case of extensive edema, meningitis, or swelling in the head and neck region, corticosteroid may be given. One or more additional antimicrobials (rifampicin, vancomycin, ampicillin, imipenem, clindamycin, or clarithromycin) are required in cases of inhalational or gastrointestinal anthrax. ${ }^{1,3,5,32,33}$

The treatment may be modified in the light of drug sensitivity pattern, once these are available. Surgical interventions are not beneficial as it can exacerbate the injury.

Two types of anthrax toxin antibodies, anthrax immune globulin and humanized monoclonal antibody can be given as adjunctive therapy. ${ }^{5}$

\section{Prevention}

1. Control of animal anthrax. $5,32,33$

2. Use of proper sterilization techniques in industrial settings dealing with animal products like hides and wools.

3. Immunization in high-risk population with anthrax vaccine adsorbed (AVA).

4. In suspected event of bioterrorism event, exposed individuals should take preexposure prophylaxis consisting of 60 days of antibiotic (ciprofloxacin or doxycycline) with or without AVA. 5.,32,33

\section{Note}

The author was selected for Dr. R.V. Rajam Oration for the year 2018-2019.

\section{Conflict of Interest}

None declared.

\section{References}

1 Thappa DM, Karthikeyan K. Anthrax: an overview within the Indian subcontinent. Int J Dermatol 2001;40(3):216-222

2 Vijaikumar M, Thappa DM, Karthikeyan K. Cutaneous anthrax: an endemic outbreak in south India. J Trop Pediatr 2002;48(4):225-226

3 Turene CY, Synder JW, Alexander DC, Bacillus and other endospore forming bacteria. In: Jorgensen JH, Pfaller MA, Carroll KC; American Society for Microbiology, eds. Manual of Clinical Microbiology, 11th ed. Washington, DC: ASM Press; 2015: 441-461
4 Nelson KE, Williams CFM, Early history of infectious disease: epidemiology and control of infectious diseases. In: Nelson KE, Williams CFM, eds. Infectious Disease Epidemiology: Theory and Practice. 2nd ed. Boston, MA: Jones and Bartlett Publishers; 2007: 3-23

5 Lucey DR, Anthrax. In: Goldman L, Schafer AI, eds. Goldman's Cecil Medicine, 24th ed. Philadelphia, PA: Elsevier; 2012:1837

6 Muturi M, Gachohi J, Mwatondo A, et al. Recurrent anthrax outbreaks in humans, livestock, and wildlife in the same locality, Kenya, 2014-2017. Am J Trop Med Hyg 2018;99(4):833-839

7 Mwakapeje ER, Høgset S, Fyumagwa R, Nonga HE, Mdegela $\mathrm{RH}$, Skjerve E. Anthrax outbreaks in the humans-livestock and wildlife interface areas of Northern Tanzania: a retrospective record review 2006-2016. BMC Public Health 2018;18(1):106

8 Gulseren D, Süzük-Yıldız S, Çelebi B, Kılıç S. Evaluation of clinical and serological findings for diagnosis of cutaneous anthrax infection after an outbreak. Cutan Ocul Toxicol 2017;36(3):289-293

9 Li Y, Yin W, Hugh-Jones M, et al. Epidemiology of human anthrax in China, 1955-2014. Emerg Infect Dis 2017;23(1):14-21

10 Denk A, Tartar AS, Ozden M, Demir B, Akbulut A. Cutaneous anthrax: evaluation of 28 cases in the Eastern Anatolian region of Turkey. Cutan Ocul Toxicol 2016;35(3):177-180

11 Thapa NK, Tenzin, Wangdi K, et al. Investigation and control of anthrax outbreak at the human-animal interface, Bhutan, 2010. Emerg Infect Dis 2014;20(9):1524-1526

12 Kracalik I, Malania L, Tsertsvadze N, et al. Human cutaneous anthrax, Georgia 2010-2012. Emerg Infect Dis 2014;20(2):261-264

13 Siddiqui MA, Khan MA, Ahmed SS, Anwar KS, Akhtaruzzaman SM, Salam MA. Recent outbreak of cutaneous anthrax in Bangladesh: clinico-demographic profile and treatment outcome of cases attended at Rajshahi Medical College Hospital. BMC Res Notes 2012;5:464

14 Chakraborty A, Khan SU, Hasnat MA, et al. Anthrax outbreaks in Bangladesh, 2009-2010. Am J Trop Med Hyg 2012; 86(4):703-710

15 Cossaboom CM, Khaiseb S, Haufiku B, et al. Anthrax Epizootic in Wildlife, Bwabwata National Park, Namibia, 2017. Emerg Infect Dis 2019;25(5):947-950

16 Eitzen E, Anthrax. In: Farrar J, Hotez PJ, Junghanss T, Kang G, Lalloo D, White NJ, eds. Manson's Tropical Diseases, 23rd ed. China: Elsevier Saunders; 2014:395-398

17 Nelson KE, Epidemiology of infectious disease: general principles. In: Nelson NE, Williams CM eds. Infectious Disease Epidemiology: Theory and Practice. 3rd ed. Burlington, MA: Jones \& Bartlett Learning; 2014:19-44

18 Glass GE, Geographic information systems. In: Nelson NE, Williams CM eds. Infectious Disease Epidemiology: Theory and Practice, 3rd ed. Burlington, MA: Jones \& Bartlett Learning; 2014:167-185

19 Nelson KE, Emerging and new infectious diseases. In: Nelson $\mathrm{NE}$, Williams CM, eds. Infectious Disease Epidemiology: Theory and Practice. 3rd ed. Nelson NE, Williams CFM eds. Burlington, MA: Jones \& Bartlett Learning; 2014:329-367

20 Grunow R, Verbeek L, Jacob D, et al. Injection anthrax-a new outbreak in heroin users. Dtsch Arztebl Int 2012;109(49):843-848

21 Berger T, Kassirer M, Aran AA. Injectional anthrax - new presentation of an old disease. Euro Surveill 2014;19(32):20877

22 Reddy R, Parasadini G, Rao P, Uthappa CK, Murhekar MV. Outbreak of cutaneous anthrax in Musalimadugu village, Chittoor district, Andhra Pradesh, India, July-August 2011. J Infect Dev Ctries 2012;6(10):695-699

23 Rao TN, Venkatachalam K, Ahmed K, Padmaja IJ, Bharthi M, Rao PA. A mini-outbreak of cutaneous anthrax in Vizianagaram District, Andhra Pradesh, India. Indian J Dermatol Venereol Leprol 2009;75(4):416-418

24 Ray TK, Hutin YJ, Murhekar MV. Cutaneous anthrax, West Bengal, India, 2007. Emerg Infect Dis 2009;15(3):497-499 
25 Rao GR, Padmaja J, Lalitha MK, et al. An outbreak of cutaneous anthrax in a non-endemic district-Visakhapatnam in Andhra Pradesh. Indian J Dermatol Venereol Leprol 2005;71(2):102-105

26 Thappa DM, Karthikeyan K. Cutaneous anthrax: an Indian perspective. Indian J Dermatol Venereol Leprol 2002;68(6):316-319

27 Thappa DM, Karthikeyan K, Rao VA. Cutaneous anthrax of the eyelid. Indian J Dermatol Venereol Leprol 2003;69(1):55

28 Vijaikumar M, Thappa DM, Jeevankumar B. Cutaneous anthrax: still a reality in India. Pediatr Dermatol 2001;18(5):456-457

29 Karthikeyan K, Bhattacharya S, Thappa DM, Kanungo R. Anthrax in an infant. Indian Pediatr 2001;38(7):777-779
30 Thappa DM. Cutaneous anthrax in two siblings. Indian J Pediatr 2001;68(6):573-574

31 Sethuraman G, Thappa DM, Karthikeyan K. Images in Medicine. Cutaneous anthrax. Postgrad Med J 2000 ;76(898):472

32 Hay HJ, Morris-Jones R, Bacterial infections. In: Griffiths CEM, Barker J, Bleiker T, Chalmers R, Creamer D, eds. Rook's Textbook of Dermatology, 9th ed. Oxford, United Kingdom: Wiley Blackwell; 2016:26.1-26.87

33 Tyring SK, Anthrax. In: Tyring SK, Lupi O, Hengge UR, eds. Tropical Dermatology, 1st ed. China: Elsevier; 2006 359-361 